Valentina Lepri

Faculty of "Artes Liberales"

University of Warsaw

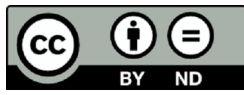

\title{
Hic liber libenter legitur in Polonia Mapping the popularity of the Zodiacus Vitae in Poland between the sixteenth and seventeenth centuries*
}

Choć Zodiacus vitae Marcellusa Palingeniusa Stellatusa był jedną z najbardziej sensacyjnych publikacji XVI stulecia, jego popularność w epoce renesansu nie stała się jeszcze przedmiotem wszechstronnych badań naukowych. Zatem celem niniejszego artykułu jest wypełnienie przynajmniej części tej luki poprzez prezentację popularności dzieła w szesnastowiecznej Polsce, gdzie pierwszego przekładu dokonał Mikołaj Rej. Faktem jest, że wielu innych wybitnych przedstawicieli kultury polskiego renesansu interesowało się Zodiacusem, na co znajdujemy liczne odwołania do tego dzieła, zarówno w utworach poetyckich, jak i traktatach filozoficznych. Ustrój ówczesnej Rzeczypospolitej oraz intensywne kontakty z niemieckimi i włoskimi uniwersytetami dają doskonałe pole do badań pogłębiających nasze rozumienie wpływu Zodiacusa na rozwój literatury i kultury pod koniec XVI i na początku XVII stulecia.

Sł ow a kl u c z ow e: Marcellus Palingenius Stellatus, literatura renesansowa, neoplatonizm, humanizm, renesans włoski

Ke ywo rds: Marcellus Palingenius Stellatus, Renaissance literature, Neo-platonism, Humanism, Italian Renaissance

* This article is part of a research project dealing with the circulation of certain works of Italian philosophical culture in late-Renaissance Poland which is being carried out in liaison with Professor Danilo Facca, whom I should like to thank for his ongoing assistance. 
All the studies dealing with the Zodiacus Vitae, and the identity of its author Marcellus Palingenius Stellatus (ca 1500 - ca 1551), make constant references to the runaway success of the book just a few years after its publication. A significant number of editions, translations and reworkings were produced to cater to readers of different tastes and expectations, but the dynamics of this immediate acclaim continue to be unclear, and the extraordinary popularity of the work in the sixteenth century has never been the subject of systematic study. Without any claim to being exhaustive, the pages that follow aim to focus certain features of this vast phenomenon which represents an important element in the history of the circulation of the Zodiacus Vitae in late Renaissance culture.

A poem in Latin hexameters, the Zodiacus Vitae, was first published in Venice, without details of edition, by the printer Bernardino Vitali around 1536. Biographical information about the author is scarce but it would appear from certain recent studies that Palingenius was a teacher originating from Campania who worked mostly in the Italian cities of Cesena and Forlì, where he was buried. ${ }^{1}$ Several years after his death, in 1558, he was condemned for engaging in magical practices, and the tribunal of the Inquisition ordered that his body be exhumed and the bones burned ${ }^{2}$ and, in the same year, the Zodiacus was included in the Index Librorum Prohibitorum.

Organised in twelve books named after the twelve constellations, it is a philosophical text which also contains numerous astrological and religious references, as well as allegorical symbolism. Palingenius describes an infinite super-celestial universe and a finite world composed of the planetary system and the earth: in this vision man is distant from God because he lives in a reality that is ontologically distinct from that of his creator. The intelligible universe is made up of incorporeal beings and pure light and is in contrast with the corporeal world inhabited by men who live in ignorance and are incapable of understanding what is good. The problem of the evil into which all men fall, apart from a few wise ones, is discussed at length in the book. The wise men pursue good by exercising their freedom, which consists in following the divine will. ${ }^{3}$

\footnotetext{
${ }^{1}$ See G. Borgiani, Marcello Palingenio Stellato e il suo poema, lo "Zodiacus Vitae", Citta di Castello 1913; F. Bacchelli, Note per un inquadramento biografico di Marcello Palingenio Stellato, "Rinascimento", 25 (1985), pp. 275-292.

${ }^{2}$ G. Borgiani, Marcello Palingenio Stellato, pp. 67-95.
} 
In the sixteenth century the poem was published in no fewer than 33 editions and was translated into both German and English. ${ }^{4}$ In France interest in the book emerged rapidly too: in 1538 poet Nicolas Bourbon (ca 1503 - ca 1550) devoted several lines to Palingenius in his Latin poem Nugae and just a few years later, in 1543, the linguist and astronomer Guillaume Postel (1510-1581) entered into polemic with Palingenius in the pages of his De Rationibus Spiritus Sancti. The French humanist criticised the position of Palingenius who, in the fifth book of the Zodiacus entitled "Leo," maintained that the man is not the ultimate aim of the universe. Early popularity in the German-speaking world is instead illustrated by numerous editions, among which those printed in Basel were the first to be published outside Italy. Indeed, the printer Ruprecht Winter (?-1553) published an edition in 1537 - that is just one year after the Venetian editio princeps of the poem - following it with another one just a few years later in 1541 .

These numerous printed editions also comprise a reworked version produced by the Polish poet Mikołaj Rej (1505-1569). His Wizerunek wtasny żywota cztowieka poczciwego was published in Cracow in 1558 and is not only a milestone in the history of Polish literature, but is also the only known case in Europe at the time of an explicit reuse of Palingenius' book. Although Rej's work is one of the liveliest expressions of the interest in the Zodiacus displayed by the Polish Renaissance, it is by no means an isolated example. On the contrary,

${ }^{3}$ M.A. Granada, Bruno, Digges e Palingenio: omogeneità ed eterogeneità nella concezione dell'universo finito, "Rivista di storia della filosofia", 47 (1992), 1, pp. 47-53; idem, Palingenio, Patrizi, Bruno, Mersenne: el enfrentamiento entre el principio de plenitud y la distinción potentia absoluta / potentia ordinata Dei a propósito de la necesidad y la infinitud del universo, in: Potentia Dei. L'onnipotenza nel pensiero dei secoli XVI e XVII, ed. G. Canziani, M.A. Granada and Y.-C. Zarka, Milano 2000, pp. 105-134.

${ }^{4}$ Johann Spreng (1524-1601) and Barnabe Googe (1540-1594) were the first to translate the Zodiacus vitae into German and English respectively. Spreng published his version in 1564, while Googe published two partial translations in 1560 and 1561 (the first three and the first six books respectively) followed by the entire work in 1565. See G. Borgiani, Marcello Palingenio Stellato; F. Bacchelli, Appunti sulla prima fortuna basileese e francese dello Zodiacus vitae del Palingenio, in: Nuovi maestri e antichi testi. Umanesimo e Rinascimento, alle origini del pensiero moderno, ed. S. Caroti, V. Perrone Compagni, Firenze 2012, pp. 167-189.

${ }^{5}$ M. Palingène, Le zodiaque de la vie (Zodiacus vitae), ed. J. Chomarat, Genève 1996 (hereafter: Palingène), p. 14. 
in Poland it immediately became a lodestone for the most brilliant thinkers and intellectuals of the time. A number of interpretations and uses of the work, partly overshadowed by the fame of the Wizerunek, can be traced, although as yet lacking sufficient attention and a general frame of reference.

The Polish readers of Palingenius already enjoyed intensive relations with the Italian intellectual world. From as far back as the time of Casimir the Great, the various ethnic and religious groups of the Kingdom of Poland were able to count on the tolerance of the central authority of the State, and in the second half of the sixteenth century the policy triggered by the Warsaw Confederation (the Compact of Warsaw, 1573) contributed to enlarging various foreign communities that comprised a considerable number of Italians. ${ }^{6}$ The circulation of knowledge was influenced in various ways and at different levels by a large number of religious exiles, artists, merchants and ecclesiastics. Moreover, contacts were also forged in the opposite direction, and the Polish nobility made a significant contribution to the exchange of ideas and the traffic of books by sending their offspring to complete their education in German and Italian universities, to the point of creating authentic colonies of compatriots gravitating permanently around prestigious universities, such as those of Padua and Bologna.

The Polish libraries still conserve no fewer than fifty sixteenth-century exemplars of the Zodiacus: most of them are the Basel or Lyons editions, but clearly such a census cannot reflect the actual presence of the work in the sixteenth-century libraries. ${ }^{7}$ If we consider the repeated expropriations suffered in more recent centuries by the Polish libraries and the resulting migration of rare collections, it seems plausible to suggest a larger number of copies, as corroborated by the ancient catalogues of public and private libraries. Even the notes regarding the first owners in the front pages of the books confirm the presence of the text in Poland, and the manuscript dedications - for example in certain sixteenth-century exemplars conserved at the National Library in Warsaw and the Jagiellonian Library of the Jagiellonian University in Cracow - confirm the passage between

${ }^{6}$ See H. Barycz, Spojrzenie w przesztość polsko-wtoska, Warszawa 1965; M. Brahmer, Powinowactwa polsko-wtoskie. Z dziejów wzajemnych stosunków kulturalnych, Warszawa 1980.

7 The data refer to the general paper catalogue of the National Library in Warsaw; the best-furnished collection, with no less than eleven copies of the Zodiacus, is the Wrocław University library. 
different owners, mostly Germans and Poles. Naturally, the group of readers in Poland of the Zodiacus also included certain illustrious Italians who had taken up residence there, such as Giovanni Michele Bruto, official historian to King Stephen Báthory. The inventory of Bruto's library was drawn up by imperial officials following his death in 1592 and, as stands to reason, it featured a large number of works by classical and modern writers that sustained the lengthy gestation of his History of Hungary. ${ }^{8}$ Cicero is one of the most recurrent names, along with Italian works including Castiglione, Ramusio and Machiavelli, while the list also records an $8^{\text {vo }}$ copy of the Zodiacus, probably one of those produced in the Basel printworks of Nikolaus Brylinger.' There are even traces of Palingenius' work in the prestigious collection of texts belonging to Giovanni Bernardino Bonifacio. It is common knowledge that the Marquis of Oria, a connoisseur of magical and hermetic knowledge and of Platonic philosophy, donated to the Senate of Danzig (Gdańsk) his 1161 books in exchange for a life annuity and on condition that they would not in future be given to the Jesuits, whom he disliked. ${ }^{10}$ In his catalogue, alongside three different editions of the De occulta philosophia by Heinrich Cornelius Agrippa and Ficino's De vita, ${ }^{11}$ there appears a printed copy of the Zodiacus indicated with the wording "Marcellus Palingenius, $16^{\circ}$ Lugduni": ${ }^{12}$ despite the owner's precautions, it is not certain that the antique

${ }^{8}$ See A. Veress, Il veneziano Giovanni Maria Bruto e la sua storia d'Ungheria, "Archivio Veneto", Quinta Serie, 1929, pp. 148-178; A. Knot, Brutus Jan Michat, in: PSB, vol. 3, Kraków 1937, p. 26; D. Caccamo, Eretici italiani in Moravia, Polonia, Transilvania (1558-1611), Firenze 1970, pp. 238-240, 1145-1152.

9 Manuscript 9639 kept in the Österreichische Nationalbibliothek in Vienna: "C.V.D. Io. Michaelis Bruti Bibliotheca Viennae Austriae post mortem eius relicta at mense mense novembri anno 1592 conscripta: ordine librorum perpetuo, nulla habita Alphabeti ratione”, Österreichische Nationalbibliothek Wien. The catalogue has 763 titles and the Zodiacus vitae is listed as number 388; see: C. Madonia, La biblioteca di Giovanni Michele Bruto, "Rinascimento", 23 (1983), pp. 261-302, in which the Viennese codex containing the inventory of his library is transcribed.

${ }^{10}$ See M. Welti, G.B. Bonifacio, marchese di Oria im Exil, Genève 1976; idem, Die Bibliothek des Giovanni Bernadino Bonifacio, marchese d'Oria, 1517-1597, Bern 1985, pp. 74-126; A. Bertini, Giovan Battista Bonifacio, "Archivio storico per le province napoletane”, 58 (1957), pp. 191-265, at pp. 249-265.

11 The first is a $4^{\text {to }}$ which was printed in Lyons, while the other two are $8^{\text {vo }}$ and were printed in Cologne and Marburg (only book four). The De vita is a $16^{\mathrm{mo}}$ Lyons edition.

12 M. Welti, Die Bibliothek des Giovanni Bernadino Bonifacio, record 755, p. 113. 
collection of the Polish Academy of Sciences library in Gdańsk still conserves the exemplar, since none of the four tomes inventoried is in a $16^{\text {mo }}$ format.

The presence of the Zodiacus in Poland, and in late sixteenth-century Europe in general, brings us up against a very full and detailed picture which is not restricted to the variegated identity of its readers and owners, but is influenced by the various ontological, gnoseological and literary contents of the text itself. Palingenius is primarily moved by an educational intention, which is already expressed in the subtitle and in the dedication to Duke Ercole of Ferrara, where he added that he expounded both religious and philosophical arguments and that he resorted in particular to the positions of the Platonists:

If anything be found in so large a work, that may seem in the least to differ from our religion, I think it is not to be imputed to me. For when I speak sometimes of philosophical matters I relate the opinions of divers philosophers, especially the Platonists. ${ }^{13}$

Despite the fact that Palingenius considers the human condition to be miserable by virtue of the nature (the substantial reality) of man, he nevertheless intends to offer a moral lesson. In the first six books, the author shows how we ought to conduct our lives correctly in order to be accepted by God. The seventh and eighth books concentrate instead on the structure of the universe, while the following two return to the question of human morality, exploiting a style that recalls that of the chivalric epic. ${ }^{14}$ Finally, books eleven and twelve address the nature of the universe, considering its different elements. The poem meshes satirical accents with theological and philosophical arguments drawn from different traditions of thought. We find Lucretian and Neoplatonic motifs, especially in the representation of God as absolutely transcendent; there is even space for a stringent criticism of the dissolute practices of the clergy.

The prefacers of the sixteenth-century editions also chose to stress different aspects of the work, at times even contributing to a certain

13 "Si tamen in tanto opere aliquid forte reperitur quod a nostra religione aliquantum dissentire videatur, mihi minime imputandum censeo. Nam dum aliquando de rebus Philosophicis loquor, diversorum Philosophorum opiniones refero, praesertim Platonicorum”, Palingène, p. 17, translated by Watson Foster.

14 G. Borgiani, Marcello Palingenio Stellato, pp. 189-190; C. Moreschini, Motivi della filosofia antica nello Zodiacus vitae di Marcello Palingenio Stellato, "Studi Umanistici Piceni”, 7 (1987), pp. 235-242, at pp. 215-216. 
ambiguity of reading. The first to insert an introductory note, Thomas Scauranus, praised its moral intentions: "gentle reader, here you have a divine epic, in which you will find delightful nourishment for your soul"; ${ }^{15}$ Johann Herold (1511 - ca 1570), instead, when introducing the German edition of 1537, compared the vast knowledge of its author to that of a physician, probably because he brings together physical and spiritual knowledge. ${ }^{16}$ Despite this, in his preface to the edition of 1547, the Dean of the Faculty of Medicine of the University of Basel, Hans Heinrich Bantlin (1522-1595), shifts attention to the lyricism inherent in the hexameters of the Zodiacus and includes a poetic eulogy by his own hand. The elegance of Palingenius' writing naturally contributed to his success, and as we know in the second half of the sixteenth century he became a textbook author - along with Prudentius and Baptista Mantuanus - for the study of Latin in English schools. ${ }^{17}$

In the same way, the Polish authors who referred to the Zodiacus in their texts favoured different aspects of the poem, and we can in general distinguish between those who read the work in an essentially philosophical key, focusing attention on the cosmology described in it, and those who laid more emphasis on its poetic-allegorical dimension and its ethical ends. In other words, these early commentators generated a diversified production, one part comprising compositions that underscored its philosophical elements and the other poems that were inspired by and imitated its lyricism and its lessons in virtuous conduct. Within this subdivision, we also have to bear in mind the fact that some works quoted Palingenius in a fairly precise manner, citing long passages, while others that are undoubtedly more difficult to analyse offered an original reworking of the contents. We have to keep these coordinates clearly in sight - the double track of interpretation of the work and the manner in which it was appropriated by its first users, through quotations or rewriting - if we want to get a clear picture of the different stages in the Polish circulation of the Zodiacus.

15 "Candide lector, habes divinum carmen: in illo / invenies animi grata alimenta tui", Palingène, p. 507.

16 The image of Palingenius as a doctor of medicine endured, and was even assumed and sustained by Giuseppe Borgiani in his monograph, see G. Borgiani, Marcello Palingenio Stellato, pp. 45-50.

17 See F. Watson, The "Zodiacus vitae" of Marcellus Palingenius Stellatus: An old school-book, London 1908. 
An astute observer of the period, the Jesuit Alfonso Pisanus, in a report on the heterodox sects present in Poland remarked on the interest that the work was arousing in the country at the end of the sixteenth century, confirming what the documentary materials now suggest:

There is a poem entitled Zodiacus, by a certain Italian named Marcellus Palingenius Stellatus. This book is very popular reading in Poland. This work, with great artifice, teaches that we must believe only in natural reasons, on the basis of which the author teaches that the world was not created but is eternal, in the manner of Aristotle, and that the angels are infinite and that this world is ruled by the devil. ${ }^{18}$

It is possible that at least a part of the Polish intellectual world had discovered the work of Palingenius long before Pisanus drew up his report, that is from the German impressions of the late 1530s. Indeed, echoes of the Zodiacus can even be discerned in Jan Dantyszek's (1485-1548) Carmen paraeneticum ad Constantem Alliopagum, ${ }^{19}$ a didactic, moralistic poem dedicated to the German Eustachy Knobelsdorf and published in Cracow in 1539 at the prestigious printworks of Hieronimus Wietor. Although the Polish humanist never explicitly cites the Latin couplets of the work, ${ }^{20}$ Dantyszek's tireless diplomatic activities, punctuated by much travel and illustrious acquaintanceships, could certainly have permitted him to be familiar with it a decade ahead of his countrymen.

In any case, the best-known example of the work's Polish success is without doubt the Wizerunek by Rej, mentioned above, belonging

18 "Extat poema nomine Zodiacus, cuiusdam Itali, nomine Marcelli Palingenii Stellati. Hic liber libenter legitur in Polonia. In eo libro magno artificio docetur credere tantum rationi naturali, iuxta quam ille autor docet creatum non fuisse mundum, sed aeternum ad modum Aristotelis et angelos esse infinitos et hunc mundum gubernari a diabolo", Synopsis sectarum praecipuarum quae simul cum catholicis sunt in regno Poloniae, MS gesuitico 844, Biblioteca Nazionale Centrale, Rome, c 4r. You can find this quotation in: V. Marchetti, Ricostruzione delle tesi antitrinitarie di Niccolò Paruta, in: Movimenti ereticali in Italia e Polonia nei secoli XVI-XVII. Atti del Convegno italo-polacco, Firenze 1974, pp. 211-268, at pp. 222-223; and also in F. Bacchelli, Palingenio e la crisi dell'aristotelismo, in: Sciences et religions. De Copernic à Galilée (1540-1610), ed. Ch.H. Lorh et al., Roma 2000, pp. 357-374, at pp. 362-363.

19 See H.B. Segel, Renaissance culture in Poland. The Rise of Humanism, 1470-1543, London 1989, p. 182.

${ }^{20}$ As a result of the project managed by Anna Skolimowska (University of Warsaw) it is possible to carry out targeted researches in the correspondence and corpus of the works of Jan Dantyszek (http: //dantiscus.ibi.uw.edu.pl/\#2). 
to the group of works by Palingenius' admirers that retrieved its poetic inspiration and underscored its moralistic aspirations. Rej's text, which is about 2,000 lines longer than the original, was first published in 1558 in a $4^{\text {to }}$ volume printed in Gothic characters by the Cracow publisher Maciej Wirzbięta (1523-1605). ${ }^{21}$ This was followed by a reprint two years later, and by a new edition published posthumously in $1565 .^{22}$ The impact of the Wizerunek on Polish culture is significant for various reasons, not least for its repercussions on the status of the language, since just a few years later in 1568 it inspired Piotr Statorius (1530-1591) to draft the Polonicae grammatices institutio, the very first Polish grammar to be printed. In this period Rej was not alone in divulging contemporary works of Italian humanistic culture, while adapting them to the social context in which he lived. Among the most widely studied writers we can mention three in particular: Łukasz Górnicki, whose Dworzanin polski, taken from Castiglione's Book of the Courtier, was printed in Cracow in 1566, Jan Kochanowski who published Szachy, inspired by the Scacchia ludus of Marco Girolamo Vida between 1564 and 1565, and his nephew Piotr Kochanowski, who devoted himself to translating the poems of Ariosto and Tasso. ${ }^{23}$ The influence of Italian writers on Polish literature was well-rooted, dating to the previous century, penetrating both the court and academic circles even before the arrival of the queen Bona Sforza and her retinue. ${ }^{24}$ Although Rej knew various Italian

${ }^{21}$ See: Polonia typographica saeculi sedecimi: Maciej Wirzbięta, Kraków 1555/1557-1605, IX-X, Zakład Narodowy Imienia Ossolińskich, Wrocław 1974-1975.

22 On the differences between $16^{\text {th }}$-century editions, see: H. Kapełuś, Porównanie szesnastowiecznych wydań Wizerunku, in: M. Rej, Wizerunk wtasny żywota cztowieka poczciwego, vols. 1-2, Wrocław 1971, vol. 1, pp. 22-32.

23 See: J. Ślaski, La letteratura italiana nella Polonia fra il Rinascimento e il Barocco, in: Cultura e nazione in Italia e Polonia dal Rinascimento all' Illuminismo, ed. V. Branca and S. Graciotti, Firenze 1996, pp. 219-151; idem, Spotkania literatury polskiej z europejska $w$ przektadach doby Średniowiecza i Renesansu, in: Przektad literacki. Teoria. Historia. Wspótczesność, ed. A. Nowicka-Jeżowa, D. Knysz-Tomaszewska, Warszawa 1997, pp. 89-107; A. Borowski, General Theory of Translation in Old Polish Literary Culture, in: Traduzione e rielaborazione nelle letterature di Polonia, Ucraina e Russia XVI-XVIII secolo, ed. G. Brogi Bercoff, M. di Salvo, L. Marinelli, Alessandria 1999, pp. 23-38; E. Ranocchi, Considerazioni sulla traduzione nella letteratura polacca premoderna. Il caso della famiglia Kochanowski, "ACME. Annali della Facoltà di Lettere e Filosofia dell'Università degli Studi di Milano”, 61 (Jan.-Apr. 2008), no. 1, pp. 51-362.

${ }^{24}$ See: D. Quirini-Popławska, Działalnośc Wtochów w Polsce w I potowie XVI wieku na dworze królewskim, w dyplomacji i hierarchii kościelnej, Wrocław 1973; 
poems of the time, it is nevertheless plausible that he discovered the Zodiacus through the channel of German culture. Indeed, in Germany the work aroused such rapid interest that even led the author's illustrious compatriot, the exiled philosopher Giordano Bruno, to misconstrue its origins when in his Oratio valedictoria to the University of Wittenberg, he numbered Palingenius among the Germans who had brought glory to their homeland. ${ }^{25}$

Rej conserved the general structure of the twelve books of the original, but did away with the signs of the zodiac, which he replaced with the names of twelve ancient thinkers. ${ }^{26}$ The constellations of Palingenius, as already noted by the Italian philosopher and physician Julius Caesar Scaliger (1484-1558) in his Poetices libri septem (1561), are none other than literary symbols that can represent the phases of human life: "and in fact, from the description of the zodiac of human life he should derive arguments to explain our lives either by analogy with the signs of the zodiac or through their power." 27 Instead, Rej entrusts his own voice to the twelve sages, and employs a more assertive style than that of Palingenius. Although Rej prefers the ancient thinkers to the astrological references, philosophy and in particular natural philosophy are not the true subject of his interest. The title of his Wizerunek actually means "the faithful image of the life of the honest man" and substantially echoes the subtitle of the text that

W. Tygielski, Wtosi w Polsce XVI i XVII wieku: utracona szansa na modernizacje, Warszawa 2005.

25 See: Oratio valedictoria, in: Iordani Bruni Nolani, Opera latine conscripta, publicis sumptibus edita, recensebat F. Fiorentino [F. Tocco, H. Vitelli, V. Imbriani, C.M. Tallarigo], vols. 1-3 in 8 parts, Neapoli[-Florentiae] 1879-1891, vol. 1, part 1, p. 17. Bruno cites Palingenius' work more extensively, analysing its doctrines, in the last two books of the De innumerabilibus, immenso et infigurabili, which was published in Frankfurt in 1591 by the publisher Johann Wechel. See: F. Bacchelli, Palingenio e Bruno, "Physis. Rivista internazionale di storia della filosofia", 38 (2001), pp. 211-221; V. Lepri, Johann Wechel, Giovan Battista Ciotti e le ultime edizioni di Bruno, "Rinascimento", 47 (2007), pp. 367-388.

26 The thinkers selected by Rey are: Hippocrates of Cos, Diogenes, Epicurus, Anaxagoras, Socrates, Theophrastus, Solinus, Plato, Zoroaster, Xenocrates, Solon and Aristotle.

27 "Etenim cum humanae vitae Zodiacum profiteretur: aut secundum signorum similitudinem, aut ex eorum vi deducere debuit argumenta ad vitam nostram explicandam", Poetices libri septem, libro sesto, 1561, in: Palingène, p. 502; see also S.F. Ryle, Fate, free will and providence in the "Zodiacus vitae" of Marcello Palingenio Stellato", in: L'uomo e la natura nel Rinascimento, ed. L. Rotondi Secchi Tarugi, Milano 1996, pp. 209-226, at pp. 212-213. 
inspired his work: "On the most excellent education for human life, for study and for practice." 28 The narrative motif centres on the figure of a youth who frequents the homes of twelve philosophers, through their help learning to distinguish vice from virtue, since each sage becomes a spiritual guide who addresses a different argument with him. The reconstruction is highly allegorical, using not only the material contained in the Zodiacus but a whole web of references and allusions to classical and modern writers. There are a number of thematic similarities in the corresponding chapters of the two works, but very few lexical correspondences and still fewer linguistic parallels. There are, nonetheless, some cases of evident reciprocity, such as the passage in the first book of the Zodiacus in which the author notes that the arguments he will be speaking of reflect our identity, and refers to the great responsibility inherent in teaching young minds that are supple and malleable:

Talk is an indication of the mind and faithful evidence of character, since every man speaks frequently and willingly of the things that are familiar to him.

The farmer talks of oxen, rakes and ploughshare, while the mariner speaks of sails and oars, hawsers and keels; the soldier's talk is full of horses, spears, swords and battles , in the same way bawdy men say many bawdy things.

I warn you, you to whom youth is entrusted and whose task it is to mould the tender minds of the young, soft to the touch as candle wax, shun these harmful writings and turn to others, that are not hollow and unworthy to be told. ${ }^{29}$

Rej's version adheres to the source to the point of citing the same exemplars and using the same terminology, such as "márynarz" for "navita" (mariner) and "wosk" for "ceras" (wax):

And speech is glad to reveal all hidden thoughts,

So that the mouth always expresses what one thinks.

28 "De hominis vita, studio ac moribus optime instituendis."

29 "Index est animi sermo, morumque fidelis / Haud dubie testis; quoniam quisque illa libenter / Et crebro loquitur, quibus oblectatur. Arator / De bobus, rastris, de vomere; navita narrat / De velis, remis, de restibus atque carinis; / miles equos memorat, gladios, hastilia, pugnas; / Sic obscoeni homines plerumque obscoena loquuntur. / Vos moneo, quorum est fidei commissa iuventus, / Et quorum est teneras puerorum fingere mentes, / Ceu molles digito ceras; haec scripta perosi / Deteriora, aliis incumbite; et illa docete, / Arida quae non sint, et non indigna referri", Palingène, pp. 29-31, vv. 195-205. 
The ploughman speaks constantly of ploughs, coulters and ploughshares,

The monk of habits, sandals and tonsures.

The knight is happy to talk of shields and lances,

At every convivial gathering each holds his own,

The hunter speaking of hounds, falcons and greyhounds;

He comes up with such things even if his nag is in a sorry state.

The mariner unfurls the sails, repairs the anchor,

Each busies himself with the things he knows,

So that the needle is never lost in the haystack.

If someone knows something, he cannot leave it aside.

And in this confusion, so many young heads

That have absorbed so many useless words into their minds,

Find this or that thought buzzing around their brains.

Until in the end they forget everything,

Since the memory moulds easily as wax everything it happens on. ${ }^{30}$

In general, the author is more faithful to his model in the first part of the Wizerunek, progressively detaching himself from it in the second, where indeed it is at times difficult to identify the direct influence of the Zodiacus. The first studies of the affinities between the Zodiacus vitae and the Wizerunek date to the second half of the nineteenth century, and the first person to systematically study the textual correspondences was Johannes Pyszkowski. ${ }^{31}$ If we analyse the

${ }^{30}$ Rej changes the order of the examples, for instance the figure of the knight comes before that of the mariner: "Bowiem káżdą skrytą myśl snádnie wyda mowá / Gdyż záwżdy gębá plecie o cżym myśli głowá: / Oracż záwzdy o pługu z trzosłem, o lemieszu, / Mnich tákież o kápicy, o trepkach, o pleszu. / Rycerz s tarczą á z drzewem wnet ná plác wyjedzie, / Á káżdy więc swą porze ná káżdey biesiedzie. / Myśliwiec też z ogáry, z rarogi, á z chárty; / Jedzie ná plác, choć szkápie będzie grzbiet odárty. / Márynarz żagle toczy kotwic popráwuie, / Á káżdy z tym, co umie, po plácu hárcuie. / Owa sie nie utái nigdy w worze szydło; / Káżdy tego, co umie, nie puści ná skrzydło. / Á ták tym zámieszániem siłá młodych głowek, / Nábrawszy w młody rozum niepotrzebnych słowek, / Teraz tym, teraz owym mysl sobie zákręci. / Áż czásem rázem wszytko wynidzie z pámięci. / Ábowiem, co chce, z wosku bárzo snádnie zlepi”, M. Rej, Wizerunk wtasny, Bk I, pp. 69-70, vv. $24 \mathrm{ff}$.

31 The first scholar to explore the affinities between the Zodiacus vitae and Wizerunek was Aleksander Tyszyński, who published an article on the subject in 1868 in the journal "Biblioteka Warszawska". However, the most detailed work of comparison was carried out by Johannes Pyszkowski. See A. Tyszyński, Wizerunki polskie. Zbiór szkiców literackich (Warszawa 1875), and J. Pyszkowski, Mikotaj Rej's "Wizerunek" und dessen Verhältnis zum "Zodiacus vitae" des Marcellus Palingenius: Dissertation zur Erlangung der Doktorwürde von der Philosophischen Fakultät der Universität Freiburg in der Schweiz (Kraków 1901). The most recent comments on the question are those of E. Sarnowska-Temeriusz, Wizerunk i Zodiacus vitae, in: M. Rej, Wizerunk wtasny, pp. 33-50. 
passages listed in his comparative tables, however, we can frequently see how Rej's reading distorts the meaning of the original, both by blurring the philosophical aspects and by neglecting the cosmological layout. A striking example of this practice, which escaped Pyszkowski or was misunderstood by him, is the alleged legacy of a passage from Book XI, dealing with Aquarius, taken up in Rej's book on Solon. In the passage from the Zodiacus - also cited by Franco Bacchelli in a recent article - he describes man stripped of all centrality in creation and the things of the world like faded images of those that inhabit the planets, in line with a vision of Platonic and Neoplatonic inspiration:

This is because the sky and every star has its citizens, there are heavenly cities and seats of the gods.

And there kings and peoples live,

but real kings and real peoples; everything is real, not, like here, shadows and empty simulacra of things, that death swiftly steals and time wears down, infects and carries off. That is where the happy, the immortal and the wise live; here mere miserable, ignorant mortals.

There peace light and the supreme will reign; here perpetual war and darkness and every type of pain. And so, go on and praise this Earth, choose this life.

Or rather, fool that you are, dare to prefer this stable to heaven. ${ }^{32}$

In Rej's poem the antithesis between the sublunar world, inhabited by simulacra, and the sky where perfection and "summa voluntas" reign, has disappeared:

What you have seen there below is Lucifer,

Who for his pride was banned from above.

And must miserably expiate in terrible suffering

His lowly condition, condemned eternally to these depths.

O miserable state, o puffed-up pride,

His unworthy revolt, his accursed, depraved scheme -

Words cannot suffice - has defeated us all,

32 "Quippe suos etiam cives habet aether et astra / singula, sunt urbes coeli sedesque deorum. / Illic et reges, populi inveniuntur et illic, / sed veri reges, populi veri, omnia vera, / non, velut hic, umbrae simulacraque inania rerum, / quas cito mors rapit et tempus terit, inquinat, aufert. / Illic foelices, immortales, sapientes, / hic habitant miseri, mortales, insipientes; / illic pax et lux regnant et summa voluntas, / hic bellum assiduum et tenebrae et genus omne doloris. / I nunc lauda Terram hanc, hanc dilige vitam, / immo aude, o demens, stabulum hoc praeponere coelo", Libro XI, Aquarius, p. 451, vv. 612-623. See also: F. Bacchelli, Palingenio e la crisi dell'aristotelismo, p. 363. 
For him we have passed from happiness to eternal anger.

Observe how the Lord above would wish to set that poor man,

Who is faithful to him, in that happy place.

But [Lucifer] in his rage at being banished from such beauty

Does all in his power to lead him astray. ${ }^{33}$

In its place we have Lucifer, his pride punished by the fall. God wants to be able to raise man to heaven, to the place left vacant by Satan but, consumed by jealousy, Lucifer does all in his power to harm man. This passage retains very little of Palingenius the philosopher, except possibly the notion of the vertical structure of the world, albeit considerably far removed from the emanationist and Neoplatonic perspective of his model.

Similarly negligent of the "opinions" 34 of the philosophers of the Zodiacus was another Polish writer active in the second half of the sixteenth century, Sebastian Fabian Klonowic (1545-1602), who also addressed Palingenius' text. Born in Kiev, which was under Polish dominion at the time, ${ }^{35}$ Klonowic dedicated his ponderous Victoria deorum, In qua continetur veri herois educatio to Mikołaj Firlej, voivode of Lublin and supporter of Calvinist ideas. Lacking information regarding the place of printing or the publisher, we can surmise that it appeared a few years after his other two carmina which were published in Cracow in 1582 and 1584: the Philtron and the better-known Roxolania, which describes Western Ukraine in Latin couplets. ${ }^{36}$ Like Rej, Klonowic draws on the Zodiacus to compose a poetic work

33 “Ten ná dole, coś widzał, to jest Lucifer on, / Co dla pychy ná gorze był márnie pogromion. / Á tu stanu swojego wiecznie w tey niskości, / Musi nędznie dokonáć w okrutney żáłości. / O nędzna mizeryjo, o pycho nádęta, / O bezecna swawola, á zła myśl przeklęta, / Á ktoż by to mógł zliczyć, co nas pogromiłá, / A z roskoszy ná srogość wieczną wypędziłá. / Pátrzajże, iż tám Pan Bog człowieká nędznego / Chce ná to miejsce wsádzić, kogo zna wiernego. / Ten z żáłości, iż zrzucon z miejscá ták wdzięcznego, / I stára sie gdzie może, áby go zwiodł z tego [...]", M. Rej, Wizerunk wtasny, Bk XI, Solon, p. 718, vv. 17-30.

34 See Palingène, p. 17.

35 See R. Ocieczek, Sebastian Fabian Klonowic - poeta epoki Odrodzenia, Kielce 1993; I. Lewandowski, Antologia poezji tacinskiej w Polsce: Renesans, Poznań 1996; S.F. Klonowic, Victoria Deorum. In qua continetur veri herois educatio (Cap. XXXI-XXXV), comp. by W. Pokrywka, Kielce 2002.

36 Sebastiani Sulmircensis Acerni Victoria deorum in qua continetur veri herois educatio, [no place and date], it is also known in a manuscript version with glosses by the author preserved in the National Library in Warsaw, Ms BOZ cim. 203. 
of educational intent: the protagonists are the gods of Olympus, who embody a new order of the world and become a model for men. Both the clergy - the order of Jesuits in particular - and the minor nobility come in for harsh criticism of the violence shown towards the Catholics, deemed the sole repositories of virtue. The pivotal subject of the poem is the definition of true nobility, identified not in birth or in the origins of a dynasty, but in the capacity of man to acquire specific professional skills. ${ }^{37}$ In his work Klonowic flaunts a marked anticlericalism, albeit without ever fully subscribing to Reformation ideas. Nevertheless, his attitude towards the connection between virtue and labour could have been influenced to some degree by Calvinist thought, which sets great store by the work ethic. The Zodiacus is not the only stylistic model for the Victoria deorum, which numbers something like twenty thousand hexameters; there are also references to the classics, including Ovid's Metamorphoses, ${ }^{38}$ Juvenal's Satires, Virgil and Horace. ${ }^{39}$

Neither Rej nor Klonowic openly quote the Zodiacus, although one of the most eminent intellectuals of the intellectual circles they frequented, Jan Kochanowski, was well acquainted with the source of the Wizerunek, and in his elegies praised the work of Rej, while in turn demonstrating his appreciation of the work of Palingenius:

Nor am I the first to press towards these cliffs,

Rej walked this path before me, earning himself esteem with almost fraternal jealousy, both for having wept for little Joseph given up to Lethe, and for having followed the example and muse of Palingenius singing of both what is proper and what is improper. ${ }^{40}$

37 See especially poem XXXV.

38 See B. Milewska-Waźbińska, O roli twórczej inspiracji (na podstawie "Zodiacus vitae" Palingeniusza i "Victoria Deorum" Klonowica), “Meander”, 44 (1989), no. 3, pp. 127-134; I. Lewandowski, Antologia poezji tacińskiej w Polsce, pp. 39-40; R. Ocieczek, Sebastian Fabian Klonowic; and M. Cytowska, "Victoria deorum" Sebastiana Fabiana Klonowica, in: Eacinska poezja w dawnej Polsce: Praca zbiorowa, ed. T. Michałowska, Warszawa 1995.

39 A.J. Mierzyński, De vita moribus scriptisque latinis Sebastiani Fabiani Acerni: accedit carmen "Roxolania", Phil. Diss. 1857, 54 ss.

40 "Nec primus rupes illas peto: Reius eandem / Institit ante viam, nec renuente Deo. / Et meruit laudem, seu parvum fleret Ioseph / Leto fraterna pene datum invidia. / Sive Palingenii exemplum Musamque secutus, / Quid deceat caneret, dedeceatque viros”, Elegy III, XIII 9-14, in: J. Kochanowski, Dzieta wszystkie. Wydanie pomnikowe, vol. 3, Warszawa 1884, p. 131. 
According to Alexander Brückner, Rej was not in possession of the cultural baggage to fully understand the social and religious objectives Palingenius set himself, while for Kochanowski his poem had the power of a catechism. ${ }^{41}$ Clearly, this is not the place to consider the traces of the Zodiacus in the boundless and multiform production of Kochanowski, but it is undeniable that his intellectual experience made him a practically ideal reader of Palingenius. His knowledge of the Platonic doctrines, for example, which put him in a position to appreciate the cosmology of the Zodiacus, was at least partially rooted in the years of his studies in Italy. Even though the Polish writer was educated in one of the major Italian strongholds of Aristotelianism of the time, the University of Padua, it seems very likely that it was precisely there that he came into contact with a thinker such as the Dalmatian philosopher Francesco Patrizi da Cherso (1529-1597). Almost the same age, Kochanowski and Patrizi were in Padua in the same period and both took an active part in the life of the university, attending the lectures held by Francesco Robortello (1516-1567) and Bernardino Tomitano (1517-1576). ${ }^{42}$ The broad intellectual horizons of the poet also had several points of contact with the education of Palingenius, comprising Epicurean philosophy, the poetry of Lucretius and Horace and even an interest in astronomy that led him to translate from Greek the educational poem in hexameters describing the constellations, the Phaenomena by Aratus of Soli.

It may perhaps have been the Zodiacus that inspired Kochanowski to express his pessimism and his anticlericalism, and to describe a god who was indifferent to the lives of men and played with their destinies. Since the last century there have been a number of scholars who have

41 A. Brückner, Mikotaj Rej. Studium krytyczne, Kraków 1905, p. 151; J. Kochanowski, Pisma zbiorowe, ed. A. Brückner, Warszawa 1924, pp. 71ff. On the influences of Palingenio in Kochanowski's works most recently writes M. Żurowski, Kochanowski and Palingenius, "Slavia Orientalis", 33 (1984), fasc. 3-4, pp. 586-599 , at p. 590.

${ }^{42}$ Franciscus Patricius was in Padua between 1547 and 1554, Kochanowski between 1551 and 1555. The former was president of the community of Dalmatian students, the latter - councillor of the Polish students; see: H. Barycz, Jan Kochanowski a Padova: i suoi maestri ed i suoi colleghi, Jan Kochanowski. Giovanni Cochanovio, poeta rinascimentale polacco, 1530-1584, Roma 1980, pp. 114-115; L. Rossetti, Jan Kochanowski e lo studio di Padova, in: Jan Kochanowski. Giovanni Cochanovio, poeta rinascimentale polacco, 1530-1584, Roma 1980, pp. 123-124; E. Marek, Jean Kochanowski. Les années d'apprentissage de l'humaniste et du poète: Pologne, Italie, France, Lille 1994. 
argued for such an influence, ${ }^{43}$ although only Brückner - and more recently Maciej Żurowski - have gone so far as to make textual comparisons, stressing the similarities between the image of man and god in the two writers and citing as examples certain famous compositions by Kochanowski, such as Cztowiek boże igrzysko or $O$ żywocie ludzkim:

Human life, everything we think is mere chaff,

Everything we do is mere chaff;

There is nothing certain in the world of men

And all we care for goes for naught:

Fame, beauty, power, glory, pride,

Money will shrivel away like the grass.

Then, having laughed enough at our antics,

Death sets us down again like puppets. ${ }^{44}$

It would, moreover, be enlightening to supplement these comparisons by searching his production for some of the key points of the systema mundi of Palingenius - such as the theory of a universe both infinite but possessed of a centre, and the philosophy of light - naturally bearing in mind that these topics were also elaborated by other writers, and in particular by Chersino who publicized them several decades after Kochanowski's Paduan sojourn when he printed his Nova de universis philosophia. ${ }^{45}$

Most of the examples we have looked at so far illustrate interest of Polish poets in the Zodiacus that gave rise to decidedly allegorical compositions, such as the Wizerunek and the Victoria deorum, which shared with the Italian writer the same commitment to moral teaching. Since he is more attentive to the philosophical than the literary aspects, Kochanowski's debt towards Palingenius is more complex and blurred. The fact that his poems are quite different in stylistic terms from the alleged model makes the work of comparison more

43 J. Langlade, Jean Kochanowski: l'homme, le penseur, le poète lyrique, Paris 1932; Z. Szmydtowa, Erazm z Rotterdamu a Kochanowski, in: eadem, W kregu renesansu i romantyzmu, Warszawa 1979; W. Weintraub, Hellenizm Kochanowskiego a jego poetyka, in: Rzecz czarnoleska, Kraków 1977; J. Pelc, Jan Kochanowski: szczyt renesansu $w$ literaturze polskiej, Warszawa 1980.

44 "Fraszki to wszytko, cokolwiek myślemy, / Fraszki to wszytko, cokolwiek czyniemy; / Nie masz na świecie żadnej pewnej rzeczy, / Próżno tu człowiek ma co mieć na pieczy: / Zacność, uroda, moc, pieniądze, sława, / Wszytko to minie, jako polna trawa; / Naśmiawszy się nam i naszym porządkom, / Wemkną nas w mieszek, jako czynią łądkom”, Fraszki I, 3.

45 See P. Zambelli, Aneddoti patriziani, "Rinascimento", 7 (1967), pp. 309-318. 
complex, in addition to the numerous other influences, including the same references to the classics that abound in the Zodiacus and that further complicate the appraisal.

The reception of Palingenius' work by the Polish writers that dealt with natural philosophy, and who developed the subject by resorting to an anthology of references to ancient and modern authorities in line with an encyclopaedic taste that began to be extremely popular towards the end of the century - is similarly marked by different forms of contamination. In several recent studies Danilo Facca has identified the case of the Franz Tidike (1554-1617) of Gdańsk. A writer of medical treatises and an esteemed teacher of philosophy at the gymnasium of Torun, Tidike had been educated in Germany, at the University of Leipzig, where he also attended lectures on Aristotelian philosophy held by Simone Simoni. In the ten treatises that make up his Microcosmus ${ }^{46}$ he presents a logical analogy between the creation of man and that of the universe in accordance with a Platonist and Neoplatonist interpretation fairly widespread in sixteenth-century Renaissance culture. The work was also known and appreciated by Bartholomäus Keckermann (ca 1572-1609), who expressed his praise in the pages prefacing the first edition of 1615 . In addition to the Zodiacus it also features various references to the Asclepius, the De magia naturalis and the Holy Scriptures.

Considering that we are dealing here with a philosophic rather than a literary text, the first question is whether Tidike drew chiefly on the Zodiacus to describe his natural philosophy. While both writers describe a cosmological model based on the coordinates of Neoplatonism, it is not possible to identify any clear analogies between their works. In other words, although the vision of Palingenius may have served as a benchmark for the drafting of the Microcosmus, it does not appear to have been his principal source of inspiration. The structure of the work and Tidike's aims and method of analysis appear to be substantially autonomous, and lead us to ask a different question: In what way did he use the Italian work?

Tidike cites the Zodiacus on three occasions, always drawing upon Book VII, indicated with the sign of Libra. The section entitled by this sign of the Zodiac deals "with the gods and with the

${ }^{46}$ F. Tidike, Microcosmus, hoc est: descriptio hominis et mundi parallēlos, in qua, quomodo in homine, ex singulari, infinita \& plus quam excellenti Dei Creatoris sapientia, universa verum natura, per imaginem quasi expressa sit [...] ostenditur, Leipzig 1615, p. 4. 
soul": ${ }^{47}$ the qualities of God are enumerated, after which those of man are described and, finally, the world in which he lives, which represents the most base and vile region of the cosmos: "the earth, so base, is home to men and animals." 48 Within this seventh book Tidike concentrates initially on the reflections devoted to an analysis of the four natural elements and cites a long passage in the fifth treatise of his Microcosmus. The Danzig philosopher is concerned to illustrate the correspondences between man and the elements: "[there are] four substances in the world, that are called elements, and the qualities of which men too display within themselves." ${ }^{2} 9$ When he turns to describe the qualities of the elements, he takes up the words of Palingenius, who considers Earth as the basest and most powerless element of all because it is heavy and less mobile, while the lighter and more mobile elements can also be considered better and more noble. The proof of his assumption lies in the fact that Earth alone, as compared to Fire, Air and Water, is unable to recompose itself when divided. ${ }^{50}$ The reference is to Epicurean and Lucretian philosophy and to the weight and movement proper to each atom, a weight that is a universal attribute of matter, and not as Democritus saw it a quality derived from the aggregation of the atoms. In addition to the weight, stress is also placed on movement as a principle of life, since "causa movendi corporibus vita est" and there are echoes of Neoplatonism and Ficino in the words of Palingenius. Beyond the philosophical positions expressed in the passage, it is clear that it is entirely functional to the reasoning of Tidike, without any emphasis being placed on other pivotal issues that are also present in the Book of Libra, such as the negative image of men or the clear distinction between the wise man and the common man in the understanding of the universe.

The other two passages that Tidike extrapolates from the Zodiacus actually make it possible to clarify not so much the affinities between the two thinkers, but rather the aspects on which they most diverge. Both quotations relate to man and are found in the last treatise of the Microcosmus, the tenth. ${ }^{51}$ The first piece exalts the pre-eminence

\footnotetext{
47 "De diis deque anima loquitur", Palingène, p. 19.

48 "est hominum sedes brutorumque infima tellus", ibidem, p. 251, v. 382.

49 "quatuor mundi corpora, quae elementa vocantur, et earum qualitates proprias, hominem etiam in se exhibere demonstrans", F. Tidike, Microcosmus, p. 294.

50 See Palingène, p. 245, vv. 217-238.

51 Treatise number ten is entitled Statuum vitae imaginem, haud sane obscuram, in homine etiam esse docens.
} 
of sight over the other senses since it is through sight, explains Palingenius, that man explores the world and comes into contact with his neighbour:

Among all these senses, the sight is deemed the most important, since it is the most important messenger channel for the mind, revealing to it the myriad things that are created by the earth through the ingenuity and the incredible virtues of nature, a thousand flowers, herbs, fruit, animals, trees, so many types of stone, so many metals; even showing us the myriad populations of Proteus' sea and all the monsters harboured by the deep; and still greater than these, the celestial temples of the gods, and the rings of the stars and the rays of the sacred sun; I shall leave out the things made by man, that no language can describe. Therefore, this sense is the finest and the best, in which it is justly believed there is the seat and principal haven of the soul; every time that we wish to see or turn to someone our eyes reach out to his eyes, as if the whole man and the whole soul lie therein. Indeed those who say that the eyes are the mirror of the soul are right, it is indeed in them that tender love kindles and there that hatred, rage, clemency, sadness, delight, cunning, piety, prudence, foolishness, ambition, anger, daring and guilt make themselves seen..$^{52}$

Sight is understood both in the Aristotelian sense of an instrument of knowledge, as it is described at the beginning of the Metaphysics, and in its Christian sense of a "lamp" of the body, as recorded in the Gospels of Luke and Matthew:

52 "Hos inter sensus praestantior esse putatur / visus; quandoquidem menti certissimus hic est / nuntius, ostendens illi quae plurima terris, / naturae ingenio ac mira virtute, creantur, / tot flores, herbas, fructus, animalia, plantas, / tam multas lapidum species, tam multa metalla; / ostendens etiam quos pascit in aequore Proteus / squammiferos populos et monstra natantia ponto; / quodque his est maius, coelestia templa Deorum, / stellarumque globos et sancti lumina solis; / mitto ea quae faciunt homines, quae lingua referre / nulla potest. Ergo hic sensus pulcherrimus atque / optimus est, in quo sedes bene creditur esse, / praecipuumque animi hospitium; quotiesque videre / aut affari aliquem volumus, tunc lumina nostra / eius in adversus oculos intendimus, ac si / totus homo atque animus totus consisteret illic. / Nempe oculos animi speculum quicumque vocarit / verus erit; nam blandus amor lucescit in illis, / apparentque odium, feritas, clementia, maeror, / laetitia, improbitas, pietas, prudentia, nec non / stultitia, ambitio, timor, ira audacia, culpa”, Palingène, p. 265, vv. 749-770. 
Your eye is the lamp of your body. When your eye is healthy, your whole body is full of light, but when it is bad, your body is full of darkness. Therefore be careful lest the light in you be darkness. If then your whole body is full of light, having no part dark, it will be wholly bright, as when a lamp with its rays gives you light. ${ }^{53}$

Acknowledgement and revelation of emotion and intention are mingled in the passage, and the sight is as much a "messenger" of the intellect as it is the channel through which "hatred, rage, clemency, sadness, delight" are revealed, since "the whole man and the whole soul lie therein." But it may be that what captured the attention of Tidike, engaged in seeking correspondences between the cosmos and man, is rather the analogy between the varietas inherent in the natural world - that the eye is capable of grasping - and the varietas of sentiments that move the human soul, which precisely through the eyes reveals itself to the world. In this case, Tidike may even have grasped Ficino-like suggestions in the reference to Proteus, in which the sea god becomes an archetype of matter lending itself to the assumption of infinite forms. ${ }^{54}$

In the last brief fragment taken from the Zodiacus the argument is the reason, which is capable of distinguishing man from other created beings:

the reason is indeed the Sun, advancing ever

in a straight line, and by virtue of which we are considered different from the beasts,

whereas opinion is like the Moon, dark and mutable. ${ }^{55}$

Taking up a classical Neoplatonist concept, Palingenius declares that reason guides the prudent, while vulgar men are led by their opinions: hence the wise seek the path of reason because it distinguishes them from animals, whereas by exercising opinion we imitate the moon that is constantly changing and sometimes dark. Together with the eye and the mind there is another salient aspect of human identity, which is emphasized continually by both Tidike

53 See Luke 11:34-36; see also Matthew 6:22-23 and Proverbs 21:4 (New International Version).

54 See N. Tirinnanzi, Umbra naturae: l'immaginazione tra Ficino e Bruno, Roma 2000, pp. 77-78.

55 "ipsa etenim ratio sol est, qui tramite recto / it semper, per quam a brutis distare putamur, / obscuram incertamque imitatur opinio lunam", Palingène, p. 247, vv. 292-294. 
and Palingenius: the use of hands. ${ }^{56}$ The significance of the hand in distinguishing humanity has ancient origins and was first expressed by Anaxagoras and later by Aristotle in De partibus animalium. It is common knowledge that the Stagirite stressed the bond between hand and intellect, arguing that the possession of the hand is a consequence of human intelligence, while Anaxagoras, reasoning in the opposite manner, considers the hand the means by which man has acquired intelligence. Citing the Zodiacus Tidike appears to embrace the Aristotelian approach, ${ }^{57}$ although he may also have had in mind other thinkers closer to him in time such as Giordano Bruno or even Ficino, who expounded this topic in a Platonic key in his Theologia:

It has also been protected by hands as the most suitable instruments for fashioning the mind's numberless inventions. The same nature would have given these instruments also to the beasts if the same inner artisan [the mind] had been present in them to make use of such instruments. ${ }^{58}$

In the natural philosophy of Palingenius and also in the Microcosmus, underlying the foundation of the cosmos is an anima mundi that creates the forms of living creatures in accordance with the Platonic model of the Timaeus. All creatures have a common matrix and all are accidents of the same matter, except for man who possesses analogies with God: this is because his mens is capable of self-determination and can bend nature through the use of techniques, ${ }^{59}$ which endorses human supremacy over other creatures. However, the image of man overcoming nature and taking up a prominent place in the cosmos is totally extraneous to the Zodiacus where, on the contrary, the ignoble and miserable condition of mankind is frequently stressed.

56 F. Tidike, Microcosmus, treatise IV, vv. 215-225, treatise VIII, p. 523.

57 See for example F. Tidike, Microcosmus, treatise VIII, p. 523 and 526.

58 "Verum mens hominis, infinitarum distinctarumque inventrix rerum, usu sermonis innumerabilis suffulta est, quasi quodam digno eius interprete; manibus quoque munita tamquam aptissimis instrumentis ad inventa mentis innumerabilia fabricanda. Quae quidem instrumenta Natura eadem dedisset et bestiis, si illis inesset artifex idem interior talibus instrumentis usurus", M. Ficino, Platonic theology, Latin text ed. James Hankins with William Bowen; English translation by Michael J.B. Allen and John Warden, vols. 1-6, Cambridge (Mass.) 2001-2006, XIII, vol. 3, pp. 182-183; see also N. Tirinnanzi, Umbra naturae, pp. 83-86.

${ }^{59}$ For a precise analysis of the contents of the Microcosmus and the philosophical references contained in it, I refer to the studies of Danilo Facca, for instance: D. Facca, Franz Tidike i kultura renesansowego neoplatonizmu, "Odrodzenie i Reformacja w Polsce", 51 (2007), pp. 93-120. 
Palingenius refuses to believe that the universe is finalized at man, noting on the contrary a heaven that is opposed to earth. The kingdom of God that he describes in his poem is not only ontologically different from the tangible world, but is also infinite, while Tidike's universe does not appear to contemplate finite and infinite and the argument is not addressed in the Microcosmus.

Although the European popularity of the Zodiacus allowed the circulation of a different cosmological model from that of strict Aristotelian observance even among non-specialist readers, it did not necessarily follow that the novel elements were always the focus of interest, as in the case of Tidike. The Polish philosopher had the type of Neoplatonist education that would have enabled him to understand the cosmos of Palingenius better than others, but he preferred to resort to its autoritas to describe its secondary aspects. ${ }^{60}$ The political and social reality of Poland at the time undoubtedly favoured a multiform reading of the work, which in some cases reflects the international context and in others brings original traits to the fore.

The most enthusiastic admirers of the poem in Europe comprised a prevalence of the Reformed, but is it possible to bring together the writers we have considered in these pages under the common banner of Antitrinitarianism, as the Pisanus Jesuit feared in his report? To make distinctions we need to consider the geography of the creeds in Poland at the end of the sixteenth century. The greatest influence of the Catholic Church was centred in Cracow and Warsaw, around which the activities of Rej and Kochanowski gravitated, despite the fact that both display distinct sympathies for the Protestant faith. The city of Lublin, on the other hand, was home not only to Klonowic but also to a thriving congregation of the Polish Brethren (Bracia Polscy), generated by the scission of the Polish Calvinists. And yet, among them Rej alone converted to Calvinism just a few years before publishing Wizerunek. Other important cities, such as Gdańsk and Toruń, frequented by Giovanni Bernardino Bonifacio and, above all, by Franz Tidike were drenched in German reformed culture, which was the reason why the civil authorities founded a number of schools there. Tidike worked at length in one of them, committed

${ }^{60} \mathrm{I}$ do not agree that the use of the Zodiacus by Tidike is a proof of his interest in astrology as suggested by Facca in his article, see: D. Facca, Franz Tidike, p. 98. Instead, it would appear that Tidike has drawn different kinds of suggestions from Palingenius' text. 
to teaching the Protestant Aristotelianism of Melanchthon, but without ever becoming a member of the circle of Antitrinitarians. Moreover, in the Zodiacus it is only the tone of the statements that was influenced by Protestant culture, while the daring religious positions appear more "a precious and singular relic of other times," 61 fruit of a Neoplatonic and Ficinian vision of the world. Despite the presence of a constant anticlericalism, the text does not deal with the Lutheran doctrine, apart from a couple of glancing references. ${ }^{62}$

It would seem more correct to say that within the space of just a few decades from the first impressions, the Zodiacus frequently appeared like an extra-confessional model from which the humanists over the border could take inspiration either for the creation of an educational poem or to shore up natural philosophy with authoritative citations. Only a handful of other Italian writers, such as Niccolò Machiavelli, Pietro Bembo and Jacopo Sannazzaro became 'classics' in such a short time, and among them still fewer were subject to such variegated readings as Palingenius was in late sixteenth-century Poland. In view of its cultural, political and geographical features, Poland can offer us a rich and articulated picture of the early circulation of the Zodiacus. Indeed, Poland proves to be a fundamental stage in the reconstruction of its popularity in general: some readers and interpreters greeted the work of Palingenius as a moral lesson, others as a philosophical system or as a rhetorical model in verse. The same dynamics of circulation held in the rest of Europe too, if we observe the phenomenon from a broader perspective that comprises an analysis of the intellectual circles of the various countries.

\section{Bibliography}

F. Bacchelli, Appunti sulla prima fortuna basileese e francese dello Zodiacus vitae del Palingenio, in: Nuovi maestri e antichi testi. Umanesimo e Rinascimento, alle origini del pensiero moderno, ed. S. Caroti, V. Perrone Compagni, Firenze 2012

F. Bacchelli, Note per un inquadramento biografico di Marcello Palingenio Stellato, "Rinascimento", 25 (1985)

61 "un relitto prezioso e singolare di altre epoche", F. Bacchelli, Palingenio e la crisi dell'aristotelismo, p. 361.

62 See Palingène, p. 417 , vv. 819-828, where we read that Pope Clement VII preferred to fight the dialectics of Luther with arms rather than words. 
F. Bacchelli, Palingenio e Bruno, "Physis. Rivista internazionale di storia della filosofia", 38 (2001)

F. Bacchelli, Palingenio e la crisi dell'aristotelismo, in: Sciences et religions. De Copernic à Galilée (1540-1610), ed. Ch.H. Lorh et al., Roma 2000

H. Barycz, Jan Kochanowski a Padova: i suoi maestri ed $i$ suoi colleghi, Jan Kochanowski. Giovanni Cochanovio, poeta rinascimentale polacco, 1530-1584, Roma 1980

H. Barycz, Spojrzenie w przesztość polsko-wtoskq, Warszawa 1965

A. Bertini, Giovan Battista Bonifacio, "Archivio storico per le province napoletane", 58 (1957)

G. Borgiani, Marcello Palingenio Stellato e il suo poema, lo "Zodiacus Vitae", Citta di Castello 1913

A. Borowski, General Theory of Translation in Old Polish Literary Culture, in: Traduzione e rielaborazione nelle letterature di Polonia, Ucraina e Russia XVI-XVIII secolo, ed. G. Brogi Bercoff, M. di Salvo, L. Marinelli, Alessandria 1999

M. Brahmer, Powinowactwa polsko-wtoskie. $Z$ dziejów wzajemnych stosunków kulturalnych, Warszawa 1980

A. Brückner, Mikotaj Rej. Studium krytyczne, Kraków 1905

D. Caccamo, Eretici italiani in Moravia, Polonia, Transilvania (1558-1611), Firenze 1970

D. Facca, Franz Tidike i kultura renesansowego neoplatonizmu, "Odrodzenie i Reformacja w Polsce", 51 (2007)

M. Ficino, Platonic theology, Latin text ed. James Hankins with William Bowen; English translation by Michael J.B. Allen and John Warden, vols. 1-6, Cambridge (Mass.) 2001-2006

M.A. Granada, Bruno, Digges e Palingenio: omogeneità ed eterogeneità nella concezione dell'universo finito, "Rivista di storia della filosofia", 47 (1992), 1

M.A. Granada, Palingenio, Patrizi, Bruno, Mersenne: el enfrentamiento entre el principio de plenitud y la distinción potentia absoluta / potentia ordinata Dei a propósito de la necesidad y la infinitud del universo, in: Potentia Dei. L'onnipotenza nel pensiero dei secoli XVI e XVII, ed. G. Canziani, M.A. Granada and Y.-C. Zarka, Milano 2000

H. Kapełuś, Porównanie szesnastowiecznych wydań "Wizerunku”, in: M. Rej, Wizerunk wtasny żywota cztowieka poczciwego, vols. 1-2, Wrocław 1971

F. Klonowic, Victoria Deorum. In qua continetur veri herois educatio (Cap. XXXI-XXXV), comp. by W. Pokrywka, Kielce 2002

J. Langlade, Jean Kochanowski: l'homme, le penseur, le poète lyrique, Paris 1932

V. Lepri, Johann Wechel, Giovan Battista Ciotti e le ultime edizioni di Bruno", "Rinascimento", 47 (2007)

I. Lewandowski, Antologia poezji tacińskiej w Polsce: Renesans, Poznań 1996

C. Madonia, La biblioteca di Giovanni Michele Bruto, "Rinascimento", 23 (1983) 
V. Marchetti, Ricostruzione delle tesi antitrinitarie di Niccolò Paruta, in: Movimenti ereticali in Italia e Polonia nei secoli XVI-XVII. Atti del Convegno italo-polacco, Firenze 1974

E. Marek, Jean Kochanowski. Les années d'apprentissage de l'humaniste et du poète: Pologne, Italie, France, Lille 1994

B. Milewska-Waźbińska, O roli twórczej inspiracji (na podstawie "Zodiacus vitae" Palingeniusza i "Victoria Deorum" Klonowica), "Meander", 44 (1989), no. 3

C. Moreschini, Motivi della filosofia antica nello Zodiacus vitae di Marcello Palingenio Stellato, "Studi Umanistici Piceni", 7 (1987)

R. Ocieczek, Sebastian Fabian Klonowic - poeta epoki Odrodzenia, Kielce 1993

Oratio valedictoria, in: Iordani Bruni Nolani, Opera latine conscripta, publicis sumptibus edita, recensebat F. Fiorentino [F. Tocco, H. Vitelli, V. Imbriani, C.M. Tallarigo], vols. 1-3 in 8 parts, Neapoli[-Florentiae] 1879-1891, vol. 1 , part 1

M. Palingène, Le zodiaque de la vie (Zodiacus vitae), ed. J. Chomarat, Genève 1996

J. Pelc, Jan Kochanowski: szczyt renesansu w literaturze polskiej, Warszawa 1980

J. Pyszkowski, Mikotaj Rej's "Wizerunek" und dessen Verhältnis zum "Zodiacus vitae" des Marcellus Palingenius: Dissertation zur Erlangung der Doktorwürde von der Philosophischen Fakultät der Universität Freiburg in der Schweiz, Kraków 1901

D. Quirini-Popławska, Dziatalność Wtochów w Polsce w I potowie XVI wieku na dworze królewskim, w dyplomacji i hierarchii kościelnej, Wrocław 1973

E. Ranocchi, Considerazioni sulla traduzione nella letteratura polacca premoderna. Il caso della famiglia Kochanowski, "ACME. Annali della Facoltà di Lettere e Filosofia dell'Università degli Studi di Milano”, 61 (Jan.-Apr. 2008), no. 1

L. Rossetti, Jan Kochanowski e lo studio di Padova, in: Jan Kochanowski. Giovanni Cochanovio, poeta rinascimentale polacco, 1530-1584, Roma 1980

S.F. Ryle, Fate, free will and providence in the "Zodiacus vitae" of Marcello Palingenio Stellato, in: L'uomo e la natura nel Rinascimento, ed. L. Rotondi Secchi Tarugi, Milano 1996

H.B. Segel, Renaissance culture in Poland. The Rise of Humanism, 1470-1543 , London 1989

Z. Szmydtowa, Erazm z Rotterdamu a Kochanowski, in: eadem, W kregu renesansu $i$ romantyzmu, Warszawa 1979

J. Ślaski, La letteratura italiana nella Polonia fra il Rinascimento e il Barocco, in: Cultura e nazione in Italia e Polonia dal Rinascimento all'Illuminismo, ed. V. Branca and S. Graciotti, Firenze 1996

J. Ślaski, Spotkania literatury polskiej z europejska w przektadach doby Średniowiecza i Renesansu, in: Przektad literacki. Teoria. Historia. Wspótczesność, ed. A. Nowicka-Jeżowa, D. Knysz-Tomaszewska, Warszawa 1997

F. Tidike, Microcosmus, hoc est: descriptio hominis et mundi parallëlos, in qua, quomodo in homine, ex singulari, infinita \& plus quam excellenti Dei 
Creatoris sapientia, universa verum natura, per imaginem quasi expressa sit [...] ostenditur, Leipzig 1615

N. Tirinnanzi, Umbra naturae: l'immaginazione tra Ficino e Bruno, Roma 2000 W. Tygielski, Wtosi w Polsce XVI i XVII wieku: utracona szansa na modernizacje, Warszawa 2005

A. Tyszyński, Wizerunki polskie. Zbiór szkiców literackich, Warszawa 1875

A. Veress, Il veneziano Giovanni Maria Bruto e la sua storia d'Ungheria, "Archivio Veneto", Quinta Serie, 1929

F. Watson, The "Zodiacus vitae" of Marcellus Palingenius Stellatus: An old school-book, London 1908

W. Weintraub, Hellenizm Kochanowskiego a jego poetyka, in: idem, Rzecz czarnoleska, Kraków 1977

M. Welti, Die Bibliothek des Giovanni Bernadino Bonifacio, marchese d'Oria, 1517-1597, Bern 1985

M. Welti, G.B. Bonifacio, marchese di Oria im Exil, Genève 1976

P. Zambelli, Aneddoti patriziani, "Rinascimento", 7 (1967)

M. Żurowski, Kochanowski and Palingenius, "Slavia Orientalis", 33 (1984), fasc. 3-4

\section{Hic liber libenter legitur in Polonia. Mapping the Popularity of the Zodiacus Vitae in Poland between the Sixteenth and Seventeenth Centuries}

Marcellus Palingenius Stellatus' Zodiacus vitae was one of the biggest editorial sensations of the sixteenth century, despite which its popularity in the Renaissance has not yet been the subject of a comprehensive study. The aim of this article is to partially fill that gap by addressing the circulation of the work in sixteenth-century Poland, where the first adaptation of the text into a language other than Latin was produced by the poet Mikołaj Rej. Indeed, several other illustrious exponents of Polish Renaissance culture were also interested in the Zodiacus and we can find references to it in both poetic works and in philosophical treatises. The particular political and social organisation of Poland at the time, and its intensive contacts with Italian and German universities, make it an excellent field of investigation for an understanding of the impact of the Zodiacus between the end of the sixteenth century and the beginning of the seventeenth.

Dr. Valentina Lepri, adjunct professor at the Faculty of "Artes Liberales", University of Warsaw; she studies the intellectual and literary culture of the Renaissance period, with special emphasis on the role of book as a medium of cultural communication. E-mail: valentina.lepri@gmail.com. 